\title{
From control of tuberculosis to control of infection: WHO recommendations for low-prevalence countries
}

One fourth of the world's population is infected by the bacillus Mycobacterium tuberculosis ${ }^{1}$. Vulnerable persons living under certain social conditions, such as the homeless or injection drug users (IDU), are at greater risk of infection, as are newly arrived immigrants from countries with a high prevalence of tuberculosis (TB). Furthermore, from $5 \%$ to $10 \%$ of the infected persons who are left untreated shall develop the disease over their lifetime, especially in the first five years after infection ${ }^{2}$. At the same time, persons who have a compromised immune system, such as those infected by the human immunodeficiency virus (HIV) are the ones most at risk of developing the disease.

The epidemiology of tuberculosis in Catalonia clearly shows a drop in prevalence in recent years, with 13.2 cases per 100,000 inhabitants in 2017. However, it should be pointed out that the level of prevalence amongst the foreign population is four times higher than that observed in the local population. In 2017, there were 35.8 and 8.4 cases per 100,000 inhabitants respectively ${ }^{3}$. The same situation can be seen in Spain as a whole, with aproximately $30 \%$ of cases born in foreign countries ${ }^{4}$. As regards the European Region of the World Health Organisation (WHO), it should be pointed out that, although the region has one of the lowest levels of prevalence of the disease, it also has the highest number of cases of multidrug-resistant tuberculosis ${ }^{5}$.

The most common risk factors for tuberculosis in Catalonia in 2017 were smoking (29.8\%), social vulnerability (20.1\%) and alcoholism (11\%). $5.3 \%$ of the cases of tuberculosis in 2017 were found to have a co-infection with $\mathrm{HIV}^{3}$.

\section{STRATEGY OF THE WORLD HEALTH ORGANISATION FOR ELIMINATING TUBERCULOSIS}

In May 2014, the WHO adopted the Global End TB strategy to intensify efforts geared towards eliminating tuberculosis worldwide, with the objective of reducing the prevalence of the disease by $90 \%$ in $2035^{6}$. The strategy in the European Region and countries with a low prevalence is directed towards reducing prevalence by $20 \%$ before 2020, by using the 2016-2020 TB Action Plan ${ }^{7,8}$. Part of the framework of this strategy for countries with fewer than ten cases per 100,000 inhabitants includes systematic screening of latent tuberculosis infection (LTBI) in specific high-risk groups that are regarded as a reservoir of the disease, whenever the local epidemiology and resources so permit, although the priority continues to be detecting cases of tuberculosis 9,10 . In particular, the application of preventive interventions to immigrants and their treatment prior to, during and after migration is possible if there is universal access to healthcare, and it should be noted that the long-term objective of eliminating tuberculosis can only be achieved if global and socio-economic inequalities in health are drastically reduced ${ }^{11}$.

The recommendations for screening are accompanied by the premise that it should be carried out with the intention to provide treatment in the event of a positive result. The development of LTBI in tuberculosis can be prevented with different preventive treatments, the efficacy of which varies between 60 and $90 \%{ }^{12}$. The benefits obtained from treatment outweigh the possible adverse effects in groups where the risk of the disease progressing is higher. With these considerations in mind, the WHO has drawn up a set of evidence-based directives to manage the screening strategy for different high-risk groups in low-prevalence countries ${ }^{13}$. 


\section{THE CONTROL OF TUBERCULOSIS AND LATENT TUBERCULOSIS INFECTION IN PRISONS}

It is estimated that the prevalence of LTBI amongst inmates of Spanish prisons is between $40 \%$ and $50 \%{ }^{14,15}$, and it is a well-known fact that the prevalence in prisons is higher than in the general population, independently of the economic status and the disease burden in each country ${ }^{16}$. In these studies, the presence of LTBI has been associated with being over 40 years of age, spending more than five years in prison and coming from countries in Eastern Europe, Sub-Saharan Africa and Latin America. A cross-sectional study carried out in a Madrid prison in 2016 found a $54.6 \%$ prevalence of LTBI and also discovered that infection by the hepatitis $\mathrm{C}$ virus acted as a predictor for presenting LTBI ${ }^{17}$.

The persons that enter prison often present one or more of the social and/or medical conditions considered to represent vulnerability to LTBI and progression to tuberculosis, such as being a recent immigrant, a homeless person, an IDU or infected by HIV ${ }^{18,19}$. In the case of the prisons in Catalonia, 93.2\% of the inmates in 2017 were men, of whom $43.2 \%$ were foreigners, most of whom came from low-income countries ${ }^{20}$. Likewise, the fact of being in an enclosed institution like a prison can favour transmission of the infection if there are smearpositive inmates present ${ }^{21,22}$. Such conditions have led to prison inmates being regarded by the $\mathrm{WHO}$ as a population at risk of infection and progression to tuberculosis, and so they recommend that systematic LTBI screening should be applied to this group ${ }^{18,23}$.

This state of affairs means that programmes designed to control tuberculosis in prisons are regarded as a vital strategy for infection control, the main objectives of which are early detection of cases of tuberculosis in order to prevent transmission and ensure that the disease is cured using directly observed therapy (DOT). This approach to dispensing treatment is essential in public health terms for controlling the disease, the treatment of which takes months, since it provides higher levels of adherence and success of the therapy in populations that are hard to reach and socially vulnerable. Furthermore, internment in prison offers a unique opportunity to carry out DOT with high probabilities of success. In Catalonia, the average time spent in prison was 520.8 days in 2017. Convicted prisoners spent an average of 699.1 days while others held in preventive custody spent an average of $135.8^{20}$. Therefore, the period that convicted inmates are held in prison favours the use of therapy without problems of adherence if they present tuberculosis.

Implementation of the TB Control Programmes commenced in Catalonia in 1985, and successfully fulfilled its objectives: LTBI screening has become a habitual practice when someone enters prison, and treatment of tuberculosis patients is carried out on $100 \%$ of cases using DOT. Such practices, along with a reduction in the prevalence of tuberculosis amongst the general population, has led to a lower number of diagnoses in prison: from 1996 to 2016, a reduction of $91.8 \%$ was observed, and in 2017 only 8 cases were reported in Catalonian prisons ${ }^{20}$. Therefore, the prison system enables strategies recommended by the WHO and the European Centre of Disease Prevention and Control (ECDC) to be effectively managed, in order to detect and treat populations at risk of LTBI and its progression to a full-blown disease, thereby contributing to reducing the infection reservoir.

The control of tuberculosis and LTBI in prisons is achieved through political commitment, partnership and financing sustained over the long term ${ }^{24}$. Continuing with and encouraging screening when entering prisons is regarded as a fundamental strategy for preventing the transmission of tuberculosis from the community to the prison environment, and for detecting and preventing LTBI, without forgetting the tremendous importance of studying contacts and the suitable isolation of the person affected every time a case of active tuberculosis is detected inside prison. Neither should the importance of screening prison personnel be forgotten, or the benefits gained from ruling out tuberculosis or LTBI in inmates before they are released, as a measure to prevent transmission from prison to the community. As regards the research on the control of tuberculosis in prisons, it is important to remember the importance of knowing about the prevalence of the disease, if it is drug-resistant, resistant or multi-resistant, and the prevalence of tuberculosis/HIV co-infection ${ }^{24}$.

All these strategies can make a major contribution to controlling tuberculosis not just in the prison setting, but also in the general population in lowprevalence countries, acting on each of the disease reservoir groups. That is why work is being carried 
out on a Guide to Latent Tuberculosis Infection, using a public health perspective, that includes all the above mentioned points, and which has the final objective of helping to control both tuberculosis infection and the disease itself.

\section{CORRESPONDENCE:}

Mireia Jané Checa

Departamento de Salud. Generalitat de Catalunya.

Barcelona

E-mail:mireia.jane@gencat.cat

Manzanares-Laya S, Jané Checa M Subdirección General de Vigilancia y Respuesta a Emergencias de Salud Pública. Secretaría de Salud

Pública. Departamento de Salud. Generalitat de Catalunya. Barcelona

\section{BIBLIOGRAPHY}

1. Houben RM, Dodd PJ. The Global Burden of Latent Tuberculosis Infection: A Re-estimation Using Mathematical Modelling. PLoS Med. 2016;13:e1002152.

2. Comstock GW, Livesay VT, Woolpert SF. The prognosis of a positive tuberculin reaction in childhood and adolescence. Am J Epidemiol. 1974;99:131-8.

3. Agència de Salut Pública de Catalunya. Informe preliminar de 2017. La tuberculosi a Catalunya l'any 2017. 2018. [Fecha de acceso: 25 Ene 2019].

4. Centro Nacional de Epidemiología. Informe epidemiológico sobre la situación de la tuberculosis en España. Año 2014. Instituto de Salud Carlos III. [Fecha de acceso: 25 Ene 2019].

5. World Health Organization. Basic facts on tuberculosis (TB) in the WHO European Region. World Health Organization Regional Office for Europe. [Fecha de acceso: 25 Ene 2019].

6. Uplekar M, Weil D, Lonnroth K, Jaramillo E, Lienhardt C, Dias HM, et al. WHO's new end TB strategy. Lancet. 2015;385:1799-801.

7. Tuberculosis action plan for the WHO European Region 2016-2020. Denmark: World Health Organization Regional Office for Europe; 2015.

8. World Health Organization. Latent Tuberculosis Infection. Updated and consolidated guidelines for programmatic management. World Health Organization: Global TB Programme; 2018.
9. Framework towards tuberculosis elimination in low-incidence countries. Geneva: World Health Organization; 2014.

10. European Centre for Disease Prevention and Control. Mathematical Modelling of programmatic screening strategies for latent tuberculosis infection in countries with low tuberculosis incidence. Stockholm: ECDC; 2018.

11. Lonnroth K, Mor Z, Erkens C, Bruchfeld J, Nathavitharana RR, van der Werf MJ, et al. Tuberculosis in migrants in low-incidence countries: epidemiology and intervention entry points. Int J Tuberc Lung Dis. 2017;21:624-37.

12. Lobue P, Menzies D. Treatment of latent tuberculosis infection: an update. Respirology. 2010;15:603-22.

13. Getahun H, Matteelli A, Abubakar I, Aziz MA, Baddeley A, Barreira D, et al. Management of latent Mycobacterium tuberculosis infection: WHO guidelines for low tuberculosis burden countries. Eur Respir J. 2015;46:1563-76.

14. García-Guerrero J, Marco A, Saíz de la Hoya P, Vera-Remartínez EJ, Grupo de estudio PREVALHEP de prisiones. Estudio multicéntrico de prevalencia de infección tuberculosa latente en los internados en prisiones españolas. Rev Esp Sanid Penit. 2010;12:79-85.

15. Marco A, Solé N, Orcau A, Escribano M, Del Baño L, Quintero S, et al. Prevalence of latent tuberculosis infection in inmates recently incarcerated in a men's prison in Barcelona. Int J Tuberc Lung Dis. 2012;16:60-4.

16. Organización Mundial de la Salud. El control de la tuberculosis en prisiones: Manual para Directores de Programas. Ginebra: OMS; 2000. [Fecha de acceso: 28 Dic 2018].

17. López de Goicoechea-Saiz ME, Sternberg F, Portilla-Sogorb J. Prevalence and associated risk factors of latent tuberculosis infection in a Spanish prison. Rev Esp Sanid Penit. 2018;20:4-10.

18. Directrices sobre la atención de la infección tuberculosa latente. Ginebra: Organización Mundial de la Salud; 2015. [Fecha de acceso: 22 Dic 2018].

19. Menzies D. Use of tuberculina skin test for diagnosis of latent tuberculosis infection (tuberculosis screening) in adults. Von Reyn CF, Baron EL, eds. UpToDate. 2018. [Fecha de acceso: 24 Dic 2018].

20. Departamento de Justícia. Descriptores estadísticos servicios penitenciarios. Generalitat de Cataluya; 2018. [Fecha de acceso: 27 Dic 2018]. 
21. Nogueira P, Abrahão R, Galesi VM. Tuberculosis and latent tuberculosis in prison inmates. Rev Saude Publica. 2012;46:119-27.

22. Baussano I, Williams BG, Nunn P, Beggiato M, Fedeli U, Scano F. Tuberculosis incidence in prisons: a systematic review. PLoS Med. 2010;7:e1000381.
23. Jagger A, Reiter-Karam S, Hamada Y, Getahun $H$. National policies on the management of latent tuberculosis infection: review of 98 countries. Bull World Health Organ. 2018;96:173-184F.

24. Dara M, Acosta CD, Melchers NV, Al-Darraji HA, Chorgoliani, Reyes H, et al. Tuberculosis control in prisons: current situation and research gaps. Int J Infect Dis. 2015;32:111-7. 